\title{
The Analysis of Grammatical Errors in University Students' Essays
}

\author{
Dewa Putu Ramendra ${ }^{1 *}$, Putu Adi Krisna Juniarta ${ }^{2}$, Ida Bagus Putrayasa ${ }^{3}$ \\ 1,2,3 Universitas Pendidikan Ganesha, Singaraja, Indonesia \\ *Corresponding author: putu.ramendra@undiksha.ac.id
}

\begin{abstract}
This study aims to identify and analyze grammatical errors in student essays. In this case, every student's grammatical error consisting of errors in the use of diction, syntactic structure and meaning were identified and described in detail within the framework of the correct grammatical rules. This research was conducted using a qualitative descriptive method because the data collected was in the form of language use, especially grammatical errors. The subject of this research is English Education Study Program students who joined essay writing courses. Meanwhile, the object of research was grammatical errors in student essays. The data were collected through the collection of student essays obtained from the end-of-semester test and interview guide. The percentage of grammatical errors made by students in their essays in sequence were as follows; fragments: $280(17.5 \%)$, runs on: 235 (14.7\%), verb forms and verb tense: $225(14.1 \%)$, passive: 220 (13.8\%), linking verb deletion: $160(10 \%)$, plural disagreement: 120 (7.5\%), unclear reference: $115(7.2 \%)$, proposition misuse 89: (5.6\%), subject-verb disagreement: 80 (5\%), and parallelism: $74(4.6 \%)$. Grammatical errors that needed to be considered more seriously were parallelism and passivity, which, although they look low in percentage terms, for they were rarely used in student essays; but when both forms were present, the grammatical construction tended to be wrong. In addition, both forms were also difficult to understand, compared to other types of errors that could be learned quickly.
\end{abstract}

Keywords: Essay, Grammatical Error

History:
Received : August 11, 2021
Revised $\quad$ :August 12, 2021
Accepted : September 13, 2021
Published : October 25, 2021

\section{INTRODUCTION}

Many believe that writing is as easy as speaking. This arises because of the assumption that writing is a recorded speech (dialogue) in written form. If speaking is easy, then writing must be easy, so it can be mastered naturally like speaking (Maulina et al., 2019; Mindog, 2016). This assumption is inaccurate and often makes students frustrated because the time and effort to learn to write is much heavier than expected. In fact, writing has an important difference when compared to speaking. First, speaking is spontaneous in a direct context. When a speaker speaks, he (she) is directly assisted by a concrete context so that the meaning can be translated easily (Selingker, 2014; Yusuf, 2020). For example, the words "I like watching this film" can easily be understood because the listener knows who I am and knows which film is meant, and maybe based on his understanding of the background the speaker knows why he likes the film. In addition, misunderstandings that may occur when interacting, whether due to vague ideas or grammatical errors, can be anticipated and corrected immediately (Llach, 2011; Putri et al., 2020; Shulze, 2003). In this way, ideas or speech messages can be conveyed and understood clearly. Third, in contrast to speaking which is acquired naturally through use in routine verbal interactions, writing is acquired through a conscious effort of learning which requires not only routine, but also a conscious and serious learning effort (Anh, 2019; Manuel, 2019).

So, writing is the most difficult language skill for language speakers, both first language speakers and even more, for second language speakers (Alghazo \& Alshraideh, 
2020; Eng et al., 2020). In the theory of first language acquisition, writing is mastered last after reading in the order of listening, speaking and reading. Writing means conveying messages or communicating through written media (Ferris, 2011; James, 2013; Keshavarz, 2012). The explanation above implies that expressing ideas in writing is a difficult task because ideas do not only contain messages, but also the structure that packs the message. This means that an idea must be packaged in such a way as to give rise to an accurate understanding according to the intended context.

How the message is structured is related to the use of correct grammar, so grammar is a very important competency. Grammatical competence includes the ability to pronounce words, phrases or sentences; mastering and using words; compose phrases and sentences; and interpret words, phrases or sentences (Corder, 1976; Radford, 1988). In other words, mastery of grammar includes mastery of phonological, morphological, syntactic and semantic which is the basis of language skills. In this case, grammatical errors cannot only interfere with fluency in reading but also make it difficult for readers to understand the content of the message. Error is one or a combination of linguistic forms, which in the same context or production situation will not be produced or made by native or first speakers (Pawlak, 2014; Uba \& Souidi, 2020). In addition, error is a form or linguistic element that is different from the linguistic norms of native speakers or any language behavior indicated by the teacher needs to be corrected (Anh, 2019; Fareed \& Bilal, 2016). Previous study distinguishes errors or deviations into two, namely errors and mistakes, which are not systematic (Ahmed, 2019; Corder, 1982). An error is a deviation from what it should be and is systematic. This systematic nature occurs because errors come from ignorance, lack of competence or which is sometimes called linguistic ignorance. Language users also tend to be oblivious when they make mistakes, let alone correct them. As a result, errors occur repeatedly and systematically. In contrast to errors, mistakes are unsystematic. Mistakes occur in performance that are coloured by, for example, fatigue, inaccuracy, or lack of concentration, etc. Mistakes are usually recognized immediately because the language user knows what is right, and can be corrected immediately.

Language errors can be measured using indicators of grammaticality, acceptability, correctness, and oddity of the use of terms and infelicity (Bartram \& Walton, 1991; Nisa, 2017). In this case, grammatical errors are related to sentence well-formedness. Grammaticality is studied, abstracted and derived from the everyday speech of native speakers. The corpus of native speaker language data is recorded and then analyzed until a rule is found that can explain how a language form is used. The language form produced is the correct form of the rule and then becomes a model to evaluate forms of language use. In general, grammatical errors can be divided into four, namely: orthographic errors, phonological errors, lexicon-semantic errors, and morph syntactic errors (Nurfitriah et al., 2018; Radford, 1988). Orthographic errors are generally caused by inconsistencies in the English spelling system. This is related to the lack of sound and spelling correspondence so that orthographic errors are easy to occur. Phonological errors are related to errors in pronouncing or voicing a language sound. Lexicon-semantic errors are related to the use of words whose meanings are not appropriate in a context. The morph syntactic errors are related to the incorrect use of the structure of words, phrases, or sentences. The types of morph syntactic errors are as follows: subject-verb agreement, plural/singular, tenses, word forms, prepositions, word order, and so on.

The uniqueness of writing is that the process is not affected by the pressure of limited time in the sense that the writer usually has enough time to think, formulate and write down the idea (message) and can convey it to the target reader if it is deemed feasible. It also means that the writer can consider the choice of words and grammar seriously to be able to produce a good writing product and free from grammatical errors. However, the reality is not like that. 
The use of proper grammar is a problem faced by most learners of English as a foreign language (Aidinlou \& Mehr, 2012; Mehta \& Al-Mahrooqi, 2014). Furthermore, grammar and lexis are one of the most problematic problems in second language acquisition (Sevy-Biloon, 2018). The results of a study by comparing IELTS essays on students of Chinese-Malaysian descent with Chinese International students at UCSI University whose lectures were all conducted in English revealed that the mistakes made were related to omission, word formation, use of word categories, word repetition, word choice, syntactic structure, coherence/cohesion, disclosure, and word order (Eng et al., 2020). The comparison results also revealed that Chinese International students made more grammatical errors compared to Chinese-Malaysian students. In addition, a study on 62 students of the Department of English Literature and Translation in the paragraph writing course revealed that the biggest mistake made by students was in the selection of prepositions followed by errors in morphology, articles, verbs, passive and active, and tenses (Abushihab et al., 2011). The source of errors comes from first language interference and weak grammatical competence. Furthermore, the study on Thai students studying English as a foreign language revealed that students' grammatical errors from the highest to the lowest were as follows: articles, word categories, prepositions, spelling, punctuation, word choice, word order and relative clauses (Phoocharoensil et al., 2016). The source of these errors comes from the influence of the first language and the complexity of English grammar.

Responding to the explanation above, the study of grammatical errors, especially in writing class, is still very important to do. In this case, this study examines grammatical errors in essays by students of English language education study program who take essay writing courses. This study aims to identify and analyze grammatical errors in student essays. In this case, every student's grammatical error consisting of errors in the use of diction, syntactic structure and meaning will be identified and described in detail in the correct framework. The results of this study are very useful as part of a systematic effort to understand the language development of learners as input for understanding the process of language acquisition (Corder, 1982). This understanding can then serve as a model that helps teachers to predict and uncover grammatical problems in the classroom and at the same time as a discussion material to consider teaching methods or techniques that can benefit students' language development and growth.

\section{METHODS}

This study uses a mixed of qualitative-quantitative descriptive method (Sugiyono, 2014). The qualitative descriptive method was chosen because the data collected were in the form of grammatical errors which included the use of and the grammatical construction of the words, phrases or sentences. This method is useful for identifying and analyzing grammatical errors in student essays. Then, a quantitative analysis was carried out to calculate the percentage of the number of errors. The analysis is done by comparing the sentences that are considered wrong and the correct syntactic sentence model (rules). If there is a deviation between the correct rules and the sentence construction used, then there is an error in the use of language. The errors will then be categorized according to their types. The subjects of this research were English students who take essay writing courses. The subjects are taken in one class for three consecutive years, from 2018-2020. This is done to collect comprehensive data with stronger findings. In this case, the number of subjects in one class ranged between 25-35 students in each batch for the 3 years. Overall, there were 97 students who were the subjects of this research. Meanwhile, the object of research is the student essays. The essay is taken from the last essay (end of semester test) after the student has attended the lecture in full. This is done to ensure that students have learned and received appropriate feedback regarding their writing skills. 
There are two methods used to collect data, namely document collection and interviews. The method of collecting documents is done by collecting student essays. The collected student essays are obtained from the results of the final semester test. The test itself is carried out at the end of the semester and contains instructions for students to write essays with a number of topics that are freely chosen by students. In addition, the interview method was carried out on students whose sentence formulations in their essays needed to be confirmed and understood what it meant so as not to cause misunderstandings. There are two instruments used to collect data, namely the end-of-semester test and interview guidelines. The final semester test consists of statements or questions for students to write essays according to the choice of topics provided. The number of words in an essay is limited to 400-750 words. Students are also given a time limit of 150 minutes to write. In addition to tests, interview guide was also used to collect data. The interview guide consisted of a number of questions that were used to explore whether students could recognize the mistakes they had made and could correct them. To perform data analysis, the steps used included (1) identification of language errors, (2) determining the element and place of the error in the sentence made, (3) explaining the error, (4) making an error classification, and (5) calculate the frequency and percentage of each classification.

\section{RESULTS AND DISCUSSION}

\section{Result}

There are a total of 97 short essays that were collected and analyzed from the three-year batch (2018-2020) of English Education Study Program students who joined the Essay Writing Course. The average number of words in each essay is 410-650 words. The types of essays written by students vary, such as narrative, description, cause or effect, comparison, illustration, classification, or argumentation with various topics. The essays were obtained from the Final Semester Examination for the Essay Writing course. The summary of the frequency and percentage of grammatical error analysis results for the 97 student essays can be seen in Table 1.

Table 1. Types of Grammatical Errors in Student Essays

\begin{tabular}{|c|c|c|}
\hline ERROR TYPES & FREQUENCY & PERSENTAGE (\%) \\
\hline Fragments & 280 & 17.5 \\
\hline Runs on & 235 & 14.7 \\
\hline Verb forms and verb tense & 225 & 14.1 \\
\hline Passive & 220 & 13.8 \\
\hline Linking verb deletion & 160 & 10 \\
\hline Plural disagreement & 120 & 7.5 \\
\hline Unclear reference & 115 & 7.2 \\
\hline Proposition misuse & 89 & 5.6 \\
\hline Subject-verb agreement & 80 & 56 \\
\hline Parallelism & 74 & 4.6 \\
\hline TOTAL & \multicolumn{2}{|c|}{1598} \\
\hline
\end{tabular}

Table 1 shows that there are 1598 grammatical errors found in student essays. If sorted from the frequency of most errors to the smallest, they are fragments: $280(17.5 \%)$, runs on: $235(14.7 \%)$, verb forms and verb tense: $225(14.1 \%)$, passive: 220 (13.8\%), linking verb deletion: 160 (10\%), plural disagreement: 120 (7.5\%), unclear reference: 115 (7.2\%), proposition misuse 89: (5.6\%), subject-verb disagreement: $80(5 \%)$, and parallelism: 74 
$(4.6 \%)$. For more details, the percentage of grammatical errors is depicted visually in Figure 1.

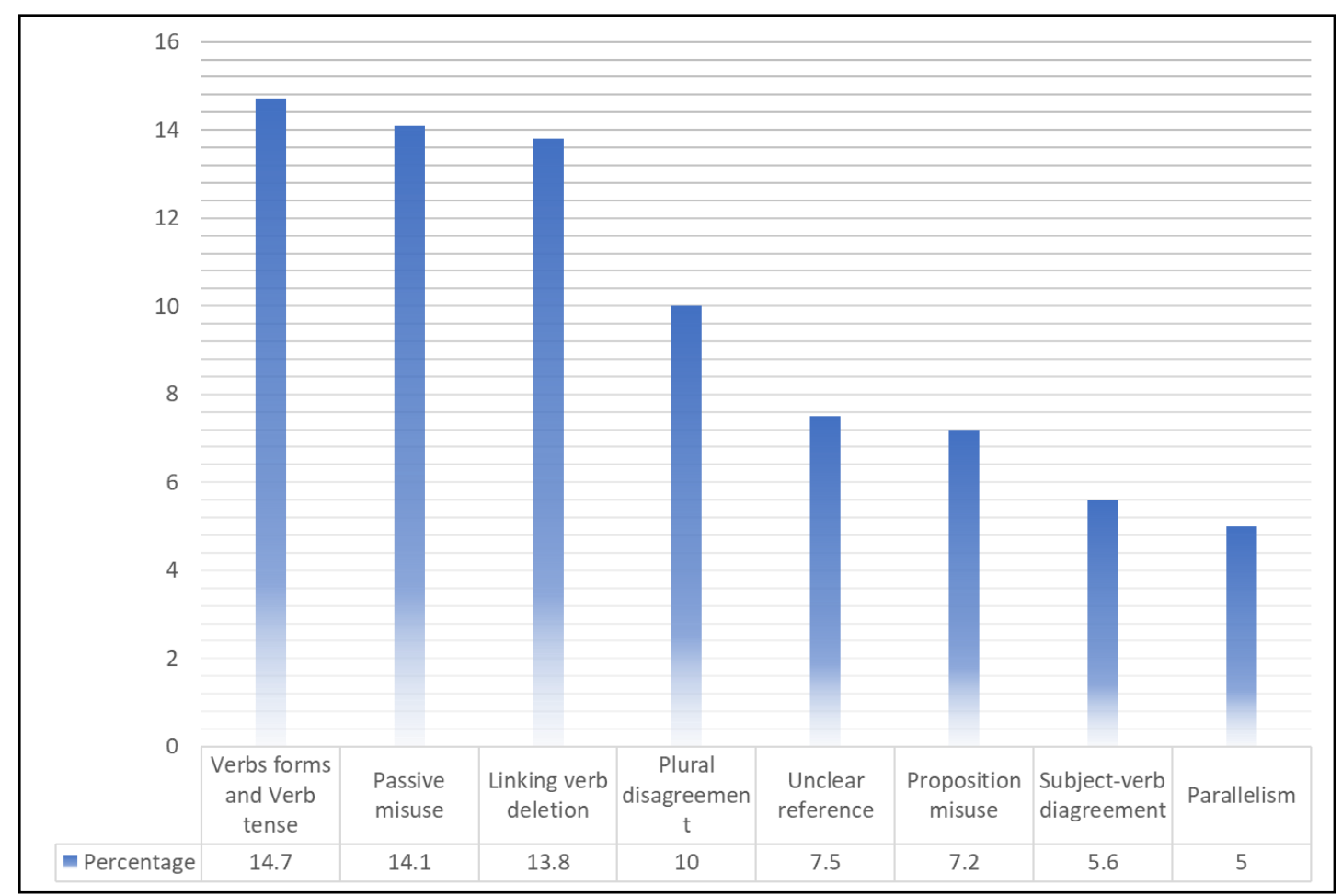

Figure 1. Types of Grammatical Errors in Student Essays

Figure 1 shows that the highest error is on fragments and the lowest is on parallelism. Between the two ranges of error types, there are also problems of run on, verb forms and verb tense, passive, linking verb deletion, plural, unclear reference, proposition misuse, and subject-verb disagreement. A more detailed description of the types of errors that students make in their essays and the sample data of incorrect sentences made are described as follows.

\section{Fragments}

Fragments occur because the sentence that is made does not have a subject or verb element. In addition, fragments can also occur due to incomplete ideas, or sentences that are only in the form of clauses or phrases, so that the sentence cannot be understood in its entirety. Examples of fragments found in the data can be seen in the following sentences (1ab).

1a. The worst social media applications like Facebook, Instagram and Snapchat when it comes to addiction.

1b. Because we never thought that can be causes for heart disease.

In sentence (1a) what is missing is a verb. Correcting the sentence (1a) can be done by inserting a verb between 'The worst social media applications - [Verb] - like Facebook, Instagram and Snapchat'; whereas in (1b) the main clause does not exist, because the form of the clause that begins with the conjunction 'because' indicates that it is a subordinate clause. This requires a main clause to become a complete sentence. 


\section{Runs on}

Runs on occurs because two or more complete sentences are put together, without appropriate punctuation marks, or are separated only by commas. Examples of runs on errors in student essays can be seen in sentences (2a-b).

2a. Students who are not passionate about learning, will be seen from the activities he is in learning, he looks lazy, often talks with his friends, attention is not focused on learning, opening books but not books that are being studied, sleeping in class, busy with HP or even the student's view is empty.

2b. Not only the internet fee but the price of the gadget is also very expensive on average now the price of the gadget that used in general is about more than two million rupiahs.

Sentence (2a) shows a number of main clauses separated by commas, even though it should be stopped by using a period to make it precise; while ( $2 b$ ) shows two sentences that become one 'not only the internet fee but the price of the gadget is also very expensive' and 'on average now the price of the gadget that used in general is about more than two million rupiahs' without an appropriate punctuation mark.

\section{Verb forms and Verb tense}

Verb forms relate to the exact form of the verb that should be used according to the context of the verb; and the verb tense is the suitability of the verb with the time it occurs. Examples of verb forms errors in student essays can be seen in sentences (3a-b).

3a. The first causes is often sit when watching television.

3b. Every worker definitely experiences work pressure

In sentence (3a), the correct form of the verb is 'sitting' because there is an auxiliary verb 'is' before it. On the other hand, in (3b) the verb form should be 'experiences' or 'is experiencing' depending on the aspect of the incident that the subject wants to reveal. In addition, subjects often make mistakes regarding verb tense in the sense that when they should use a past tense, they use the present tense verb. Examples of verb forms errors in student essays can be seen in sentences (3c-d).

3c. My mother cook some rice for me yesterday.

3d. We play Facebook together

The form of the verb that should be used in (3c) and (3d) respectively is the past tense 'cooked' and 'played' according to the time context of the writing.

\section{Passive misuse}

Passive is related to giving focus to the object, not the subject by moving the object to the position of the subject. This moves also serves to hide the subject. Passive grammatical realization is be + third past verb. Examples of passive misuse errors in student essays can be seen in sentences (4a-b).

4a. So, the excess will be keep by our body as fat.

4b. So, they will end their life because they lost something precious, it happens because they have an unstable emotion and then cannot make a right decision.

In sentence (4a) after 'be', the verb form that should follow is 'kept'; and in (4b) besides the runs on error, there is also a passive construction error, which before the third verb 'ended', after 'will', there should be a 'be'.

\section{Linking verb deletion}

Linking verbs are verbs that bridge the subject with words that describe the subject; in this case, the verb has no special meaning. Examples of linking verb deletion errors can be seen in sentences $(5 a-b)$. 
5a. The teenagers will get sick and they will do anything to get the drug.

$5 \mathrm{~b}$. In the other side, a lot of people that late to sleep have big chance to get fat.

Sentence (5a) shows a linking verb deletion error because there is no 'be' between 'will' and 'busy'; The 'be' in that sentence can function as a linking verb that connects the subject 'they' and the descriptor 'busy'. On the other hand, in (5b) after 'that' there should be a linking verb 'are'.

\section{Plural disagreement}

Plural disagreement relates to a mismatch between the number of quantifiers and the number of nouns referred to. Examples of quantifiers are a, a few, some, several, many, a lot of, all, and others. In this case, if the quantifiers indicate that the number of objects referred to is plural, then the form of the noun referred to should also be plural (-s). Examples of plural errors in student essays can be seen in sentences (6a-b).

6a. There is some effect from cigarette about healthy disorders namely your blood pressure and heart rate will increase.

6b. I saw some mice in the market.

In the sample sentence (6a), the use of 'some' should be followed by 'effects' and in (6b) 'mouse' it should be 'mice' to indicate the plural number (plural).

\section{Unclear reference}

Unclear reference is related to the unclear reference of the pronoun to the entity (noun) being referred to. This can happen because there are several nouns in the sentence that the pronoun can refer to. The examples of unclear reference errors in student essays can be seen in sentences $(7 a-b)$.

7a. The use of computers, mobile phones, and various gadgets to access online platforms by students may harm the user if they use it for long hours frequently.

7b. Do everything that we like and take holiday time if you need it.

Sentence (7a) has the noun computers, mobile phones, and various gadgets; students; and the user', which in this case, the pronoun term 'they' is not clear which noun refers to. In sentence (7b), the pronouns 'we' and 'you' do not clearly refer to who or where.

\section{Preposition misuse}

Prepositions serve to connect nouns, pronouns, or verbs with related information. Examples of prepositions are at, on, in, about, of, from, since, and so on. The examples of misuse of preposition errors in student essays can be seen in sentences (8a-b).

$8 \mathrm{a}$. The most often problem that causes of excessive use of gadgets is economic problems.

8 b. Those causes are affected to the teenagers.

Sentence (8a) shows the wrong use of the preposition 'of', because in that context the most appropriate preposition to use is 'by'. On the other hand, in ( $8 b)$ in addition to the error in determining the voice, the use of the preposition 'to' is also wrong. 'To' should be deleted.

\section{Subject-Verb disagreement}

Subject-verb disagreement occurs when there is no match between the subject and the verb in terms of number. If the subject is singular or uncountable, the verb should end in -s; However, if the subject is plural, then the verb does not end in $-\mathrm{s}$. The examples of subjectverb disagreement errors in student essays can be seen in sentences (9a-b).

9a. It happens because people with overweight have more fat in the body.

$9 \mathrm{~b}$. My best friend love coffee very much. 
Sentences (9a) and (9b) are incorrect because the verbs used sequentially are 'happen' and 'love,' even though the subject is singular. Instead, 'happen' should be replaced with 'happens'; and 'love' with 'loves'.

\section{Parallelism}

Parallelism relates to the use of a balanced structure in the same parts of a sentence. In this case, nouns are paired with nouns, verbs with verbs, phrases that match their word class with appropriate phrases, and so on. Examples of parallelism errors in student essays can be seen in sentences (10a-b).

10a. There are several negative effects from social media for students namely waste their time, low grades, unhealthy sleep patterns, and general addiction

10b. If you are already addicted, students will forget to study, waste time, and their grades decrease.

Sentence (10a) is not parallel because 'waste their time' (verb phrase), paired with 'low grades' (noun phrase), 'unhealthy sleep pattern' (noun phrase), and 'general addiction' (noun phrase). Sentence (10b) is also not parallel because 'forget to study' (verb phrase) and 'waste time' (verb phrase) are paired with the main clause 'their grades decrease'.

\section{Discussion}

The uniqueness of writing is that the process is not affected by the pressure of limited time in the sense that the writer usually has enough time to think, formulate and write down the idea (message) and can convey it to the target reader if it is deemed feasible. It also means that the writer can consider the choice of words and grammar seriously to be able to produce a good writing product and free from grammatical errors. However, the reality is not like that. The use of proper grammar is a problem faced by most learners of English as a foreign language (Aidinlou \& Mehr, 2012; Mehta \& Al-Mahrooqi, 2014). Furthermore, grammar and lexis are one of the most problematic problems in second language acquisition (Sevy-Biloon, 2018). The results of a study by comparing IELTS essays on students of Chinese-Malaysian descent with Chinese International students at UCSI University whose lectures were all conducted in English revealed that the mistakes made were related to omission, word formation, use of word categories, word repetition, word choice, syntactic structure, coherence/cohesion, disclosure, and word order (Eng et al., 2020). The comparison results also revealed that Chinese International students made more grammatical errors compared to Chinese-Malaysian students. In addition, a study on 62 students of the Department of English Literature and Translation in the paragraph writing course revealed that the biggest mistake made by students was in the selection of prepositions followed by errors in morphology, articles, verbs, passive and active, and tenses (Abushihab et al., 2011). The source of errors comes from first language interference and weak grammatical competence. Furthermore, the study on Thai students studying English as a foreign language revealed that students' grammatical errors from the highest to the lowest were as follows: articles, word categories, prepositions, spelling, punctuation, word choice, word order and relative clauses (Phoocharoensil et al., 2016). The source of these errors comes from the influence of the first language and the complexity of English grammar.

The errors made by students in essays seem to be many, but in general these errors do not interfere with understanding because there are almost no problems in diction. In this case, the written essay can be understood quite easily because the error is not significant. For example, fragments error which is the most error is not a big problem, because through context and relationship between sentences, readers can understand the essay easily. Meanwhile, the run on error can be solved quite easily by putting a period, or a semicolon (comma) and conjunctions. Other errors are also of the same type, but that does not mean 
those errors do not need any attention because they are still important. These errors indicate the need for a serious pedagogical intervention.

Errors in verb forms and verb tense, linking verb deletion, plural disagreement, unclear reference, preposition misuse and subject-verb agreement are not massive and comprehensive, but in some essays it seems that many indicate a lack of deep understanding of certain grammatical sub-points, even though theoretically, students generally understand what verb forms and verb tense, linking verb, plural, reference, preposition, and subject-verb agreement are. Grammatical errors that need to be taken more seriously are parallelism and passivity, although they seem low in terms of frequency or percentage. This is because the two grammatical forms rarely colour student essays; but when the forms are present, both forms tend to be formulated incorrectly. Regarding parallelism, students tend to think that all forms can be paired (or paralleled) as long as the form 'and' or 'or' is present in the sentence. This is certainly a misconception, because parallel forms mean that only grammatical forms of the same kind can coexist, for example, nouns with nouns, verbs with verbs, and so on. In making passive sentences, students understand that the formula is be (helping verb) + third past verb. However, the application of the language formula is difficult for them to apply so that they are often confused or forget the 'be'; and often when writing the third past tense, they write first present or second past tense. Students do not seem to understand the complexities of passive sentences.

\section{CONCLUSION}

Grammatical errors that need to be considered more seriously are parallelism and passivity, which, although they look low in percentage terms, are rarely used in student essays; but whenever the two forms are present, the sentence constructions are made consistently wrong. Based on this conclusions, some suggestions are given as follows. First, these types of errors seem to need to be explored from other perspectives, for example from a psychological or pedagogic perspective to obtain a complete, comprehensive and thorough understanding. In addition, the results of this study can also be continued into a more tangible and more important follow-up, namely, how to use it for pedagogic purposes, in accordance with the view that language errors open a window for a pedagogical understanding.

\section{ACKNOWLEDGMENTS}

This short section is for thanking the institutions and individuals who helped significantly in the work reported in the paper, specifically a granting agency that supplied funds or a laboratory that supplied materials

\section{REFERENCES}

Abushihab, I., El-Omari, A. H., \& Tobat, M. (2011). An Analysis of Written Grammatical Errors of Arab Learners of English as a Foreign Language at Alzaytoonah Private University of Jordan. European Journal of Social Sciences, 20(4), 543-552. https://www.iasj.net/iasj/article/96110.

Ahmed, F. E. Y. (2019). Errors of Unity and Coherence in Saudi Arabian EFL University Students' Written Paragraph: A case Study of College of Science \& Arts, Tanumah, King Khalid University, Kingdom of Saudi Arabia. European Journal of English Language Teaching, 4(3), 125-155. https://oapub.org/edu/index.php/ejel/article/view/2281.

Aidinlou, N. A., \& Mehr, H. S. (2012). The Effect of Discourse Markers Instruction on EFL 
Learners' Writing. World Journal of Education, 2(2), 10-16. https://eric.ed.gov/?id=EJ1158965.

Alghazo, K. M., \& Alshraideh, M. K. (2020). Grammatical Errors Found in English Writing: A Study from Al-Hussein Bin Talal University. International Education Studies, 13(9), 1-9. https://eric.ed.gov/?id=EJ1266480.

Anh, D. T. N. (2019). EFL student's writing skills: challenges and remedies. IOSR Journal of Research \& Method in Education, 9(6), 74-84. https://doi.org/10.9790/73880906017484.

Bartram, M., \& Walton, R. (1991). Correction: A Positive Approach to Language Mistakes. Cengage Learning.

Corder, S. P. (1976). The Significance of Learner"es Errors. 1RAL, 5, 161-170.

Corder, S. P. (1982). Error Analysis and Interlanguage. Oxford University Press.

Eng, L. S., Luyue, C., \& Lim, C. K. (2020). A Comparison of the English Grammatical Errors of Chinese Undergraduates from China and Malaysia. International Journal of Instruction, 13(1), 931-950. https://eric.ed.gov/?id=EJ1239318.

Fareed, M., \& Bilal, M. (2016). ESL Learners 'Writing Skills : Problems , Factors and Suggestions ESL Learners 'Writing Skills: Problems, Factors and Suggestions Introduction. Journal of Education and Social Sciences, 4(2), 81-92. https://doi.org/10.20547/jess0421604201.

Ferris, D. R. (2011). Treatment of Error in Second Language Student Writing. The University of Michigan.

James, C. (2013). Errors in Language Learning and Use: Exploring Error Analysis. Routledge.

Keshavarz, M. H. (2012). Contrastive Analysis and Error Analysis. Rahnama Press.

Llach, M. P. A. (2011). Lexical Errors and Accuracy in Foreign Language Writing. Multilingual Matters.

Manuel, M. P. (2019). Belief System Towards Explicit Corrective Feedback in EFL Classroom: The Case of Foundation Students of OMAN. College Health Sciences, 4(3), 50-59. https://www.oapub.org/edu/index.php/ejel/article/view/2262.

Maulina, U., Hikmah, S., \& Pahamzah, J. (2019). Attractive Learning Media to Cope with Students' Speaking Skills in the Industry 4.0 Using Sparkol Videoscribe. Online Submission, 2(5), 132-140. https://eric.ed.gov/?id=ED598724.

Mehta, S. R., \& Al-Mahrooqi, R. (2014). Can thinking be taught? Linking critical thinking and writing in an EFL context. RELC Journal, 46(1), 23-36. https://doi.org/10.1177/0033688214555356.

Mindog, E. (2016). Apps and EFL: A case study on the use of smartphone apps to learn English by four Japanese university students. JALT CALL Journal, 12(1), 3-22. https://doi.org/10.29140/jaltcall.v12n1.199.

Nisa, B. (2017). Kesalahan Tata Bahasa (Grammar) pada Makalah Mahasiswa Program Studi Bahasa Inggris ABA BSI Jakarta. Wanastra, 9(1), 17-23. https://ejournal.bsi.ac.id/ejurnal/index.php/wanastra/article/view/1436.

Nurfitriah, Nai'mah, R. J., \& Adriyati, R. (2018). Analisa Kesalahan Gramatikal Mahasiswa dalam Membuat Kalimat-Kalimat Sederhana Menggunakan Bahasa Inggris. Prosiding Seminar Nasional ASBIS 2018.

Pawlak, M. (2014). Error Correction in The Foreign Language Classroom: Reconsidering The Issues. Springer_Verlag.

Phoocharoensil, S., Moore, B., Gampper, C., Geerson, E. B., Chaturongakul, P., Sutharoj, S., \& Carlon, W. T. (2016). Grammatical and Lexical Errors in Low-Profieciency Thai Graduate Students' Writing. Language Educatioon and Acquistion Research Network (LEARN) Journal, 9(1). https://eric.ed.gov/?id=EJ1229539. 
Putri, M., Ariyani Pedo, V., \& Pawestri, N. (2020). Analyzing the Factors Influencing Students' Fluency in English Speaking Skills: A Case in Bina Nusantara University. ICLLT 2019. https://doi.org/10.4108/eai.12-10-2019.2292184.

Radford, A. (1988). Transformational Grammar: A First Course. Cambridge University Press.

Selingker, L. (2014). Interlanguage. In J. C. Richards (Ed.), Error Analysis: Perspectives on Second Language Acquisition (pp. 31-54). Taylor and Francis.

Sevy-Biloon, J. (2018). Integrating EFL Skills for Authentically Teaching Specific Grammar and Vocabulary. Studies in English Language and Education, 5(2), 175-184.

Shulze, M. (2003). Grammatical Errors and Feedback: Some Theoretical Insights. CALICO Journal, 20(3), 437-450. https://www.jstor.org/stable/24157523.

Sugiyono. (2014). Metode Penelitian Pendidikan Pendekatan Kuantitatif, Kualitatif, dan $R \& D$. Alfabeta.

Uba, S. Y., \& Souidi, N. M. (2020). Students' writing difficulties in English for business classes in Dhofar University, Oman. International Journal of Higher Education, 9(3), 86-97. https://doi.org/10.5430/ijhe.v9n3p86.

Yusuf, R. (2020). Teaching EFL Students Using Selected Media: Offline Video Taken From YouTube. Utamax : Journal of Ultimate Research and Trends in Education, 2(1), 2933. https://doi.org/10.31849/UTAMAX.V2I1.2909. 